\title{
IMPLEMENTASI NILAI-NILAI PENDIDIKAN ISLAM DALAM AKTIVITAS REMAJA MASJID IMAM RIJALI IAIN AMBON
}

\author{
Sadila Salma Walalayo ${ }^{1}$ \\ Prodi PAI FITK IAIN Ambon ${ }^{1}$ \\ sadila@iainambon.ac.id
}

\begin{abstract}
The result of this study that the from of the Rijali IAIN Ambon Imam mosque youth programs that contains, the value of Islamic education is . 1). Preaching or preachers programs, Islamic studies programs, Community comford programs, Cooperative programns and government programs. This programs was formed by means of deliberations between the chairman of the Takmir mosque, the youth of the mosque, and other members. 2). Activities that contain the value of Islamic education including for women there are certain assignments including: a). cleaning the veil, b). reviewing women's jurisprudence studies, c). training young preachers training, d). lecturing training, e). tahlil training, f). yasinan, g). cult before zhuhur prayer as well as Islamic studies, and big day celebrations Islamic. The implementation of Islamic values contained in the activities of the youth of the Imam Rijali IAIN Ambon mosque itself includes character formation, monotheism, worship $n$ the morals. Islamic values are implemented through the program activities that exist in the youth mosque the Imam of the Ambon. Including the student component itself which was fully supported by the head of the mosque's takmir Rijali IAIN Ambon.
\end{abstract}

Keywords: Implementation of Islamic values, Adolescent mosque.

Abstrak: Hasil penelitian ini bahwa bentuk program Remaja Masjid Imam Rijali IAIN Ambon adalah, 1). Program dakwah atau mubaligh, Program kajian kelslaman, Program kenyamanan umat, Program koperasi dan Program keputrian. Program-program ini dibentuk dengan cara bermusyawarah antara ketua takmir masjid, ketua remaja masjid dan para anggota lainnya. 2). Aktivitas yang mengandung nilai pendidikan Islam diantaranya untuk para akhwat ada tugas-tugas tertentu antara lain: a).Pembersihan mukena-mukena,b).Kajian - kajian fiqih wanita, c). Pelatihan-pelatihan mubaligh-mubaligh muda, d). Pelatihan ceramah, e). Pelatihan tahlil, f). Yasinan, g). Kultum sebelum shalat zhuhur serta kajian-kajian kelslaman, dan perayaan hari-hari besar Islam. Implementasi nilai-nilai Islam yang terdapat dalam aktivitas remaja masjid sendiri yaitu meliputi pembentukan karakter, ketauhidan, ibadah serta akhlak. Nilai-nilai Islam itu di terapkan melalui aktivitas program yang ada di Remaja Masjid Imam Rijali IAIN Ambon tersebut. Dengan adanya implementasi nilai-nilai Islam ini sangat mempengaruhi bagi remaja masjid termasuk didalamnya komponen mahasiswa itu sendiri yang sepenuhnya mendapat dukungan ketua takmir masjid.

Kata kunci: Aktivitas Remaja Masjid, Nilai-Nilai Pendidikan Islam 


\section{PENDAHULUAN}

Dalam menjalani kehidupan ini, manusia tidak bisa lepas dari pendidikan, kerana pendidikan merupakan upaya sadar untuk membantu manusia menemukan jati dirinya, sehingga bisa mengetahui dari mana ia berasal, tercipta dari apa, mengapa ia diciptakan dan kemana kelak ia akan kembali, kemudian akan mempertanggungjawabkan semua perilakunya selama hidup. Dilihat dari segi pendidikan Islam, maka akan ditemukan betapa Rasulullah SAW pada awal Islam sudah sangat konsen dalam pendidikan Islam, beliau mulai mendidik dan mengajari umatnya (sahabat) di rumah salah satu sahabat beliau yang bernama al-Arqam bin Abi al-Arqam atau biasa disebut dengan Daru al-Arqam yang bertempat di Mekah, di rumah inilah beliau mengadakan pertemuan dan pengajaran dengan para sahabat, ketika itu jumlah pengikut beliau masih sangat sedikit akan tetapi hari demi hari pengikutnya semakin bertambah. ${ }^{1}$

Masjid pada awalnya merupakan tempat pusat segala kegiatan. Bukan saja sebagai pusat ibadah khusus, seperti shalat dan l'tikaf. Akan tetapi masjid merupakan pusat kebudayaan muamalat. Masjid merupakan tempat lahir kebudayaan Islam yang demikian kaya dan berkah. Kejayaan umat Islam yang tertulis dalam lembaranlembaran Sejarah Peradaban Islam tidak bisa dilepaskan dari proses pendidikan Islam di masjid.

Fungsi masjid sebagai tempat pendidikan merupakan fakta sejarah yang sulit untuk ditolak. Hal ini didasarkan bahwa masjid telah digunakan sebagai tempat pendidikan sejak berabad-abad awal perkembangan dakwah Islam. Bahkan hingga kini, budaya ta'lim yang digunakan di masjid masih mudah ditemui. Masjid dapat juga berfungsi sebagai pembentukan karakter dan moral masyarakat sekitar melalui berbagai macam kegiatan bimbingan dan arahan. Jika berbicara tentang masjid, maka

\footnotetext{
${ }^{1}$ Moh Roqib, Menggugat Fungsi Edukasi Masjid (Purwokerto: STAIN Purwokerto dan Grafindo Litera Media, 2005), hlm 73.
} 
tidak terlepas dengan peran remaja masjid. Pada masa dahulu, peran remaja masjid sangatlah penting terutama dalam mengembangkan dakwah Islam. ${ }^{2}$

Remaja sebagai generasi muda muslim pewaris dakwah masjid, yang sudah seharusnya memiliki sikap dan perilaku sebagai muslim yang baik. Pemikiran, perkataan, dan perbuatannya senantiasa didasari oleh nilai - nilai Islam. Gerak dan aktivitasnya berada dalam sebuah siklus, yaitu beriman, beramal shalih, dan beramar ma'ruf nahi munkar. Remaja masjid sendiri merupakan salah satu organisasi independen yang dibentuk oleh masjid sebagai kepanjangan tangan dari takmir masjid. Remaja masjid memiliki wewenang dalam menentukan sendiri mengenai struktur organisasi, memilih pengurus, menyusun program serta melaksanakan berbagai macam kegiatan. Dengan hal ini, para aktivitasnya memiliki kesempatan untuk berkreasi, mengembangkan potensi, serta beraktivitas dalam amal jama'i. ${ }^{3}$

Remaja pada dasarnya merupakan pewaris generasi bangsa yang juga menjadi regenarasi dakwah di masa yang akan datang. Maka melihat hal tersebut masjid bukan hanya berfungsi sebagai tempat ibadah namun juga sebagai tempat peradaban umat. Dalam hal ini penulis melihat salah satu masjid yang terletak di daerah kampus IAIN Ambon. Masjid ini adalah masjid Imam Rijali IAIN Ambon yang telah berdiri kokoh, dan masjid ini merupakan salah satu masjid yang merupakan sumbangan dari Yayasan Amal Bakti Muslim Pancasila. diresmikan pada tanggal 21 Oktober 1995 oleh Presiden RI yang kedua Soeharto. Letak masjid Imam Rijali IAIN Ambon ini terletak di tengah kampus IAIN Ambon dan merupakan masjid kampus IAIN Ambon.

\section{METODE}

Untuk mengetahui bentuk program remaja masjid Imam Rijali IAIN Ambon yang mengandung nilai pendidikan Islam dan aktivitasnya, yang mengandung nilai pendidikan Islam akan digunakan jenis penelitian kualitatif. Penelitian deskriptif itu berusaha untuk memperoleh gambaran secara lengkap dan detail tentang kejadian dan fenomena tertentu pada suatu objek dan subjek yang memiliki kekhasan. Dengan demikian pelaksanaan penelitian adalah menggali informasi sebanyak-banyaknya dan sedalam-dalamnya kemudian mendeskripsikan dalam bentuk naratif sehingga

\footnotetext{
${ }^{2}$ Sofyan Safri Harahap, Manajemen Masjid, (Yogyakarta: Dhana Bhakti Prima, 1996), hlm.5.

${ }^{3}$ Ahmad Sarwono, Masjid Jantung Masyarakat (Yogyakarta : Izzan Pustaka, 2003), hlm. 15.
} 
memberikan gambaran secara utuh tentang fenomena yang terjadi. Penulis akan menggunakan tiga metode dalam pengumpulan data dan informasi yaitu wawancara, observasi dan dokumentasi serta teknik analisis data terdiri dari reduksi data, penyajian data dan verifikasi data.

\section{HASIL}

\section{Bentuk program Remaja Masjid Imam Rijali IAIN Ambon yang mengandung nilai pendidikan Islam}

Dalam dunia pendidikan Islam tidak bisa dipisahkan dari keberadaan sebuah Masjid. Hal ini dikarenakan masjid menjadi sentral tempat pensyiaran pendidikan agama Islam yang sudah berlaku mulai zaman Nabi Muhammad SAW. Hingga saat ini, para umat muslim tetap memanfaatkan masjid sebagai tempat beribadah sekaligus sebagai lembaga pendidikan keagamaan seperti pembentuk TPQ, remaja masjid, ta'mir masjid dan juga disertai dengan kegiatan-kegiatan keagamaan yang mendukung seperti yasinan, tahlil dan pengajian rutin. Kegiatan-kegiatan yang dilakukan di masjid kebanyakan diikuti oleh mahasiswa dan para dosen. Sementara untuk para sebagian mahasiswa jarang sekali yang mengikutinya, terlebih lagi untuk bergabung dalam organisasi Islam seperti Remaja Masjid. Kondisi tersebut disebabkan adanya krisis moral yang melanda sebagian mahasiswa Melihat remaja Masjid Imam Rijali IAIN Ambon yang tetap eksis dari jaman dulu sampai sekarang dengan selalu mencoba dan berusaha dengan cara memfungsikan masjid sebagai pusat pendidikan keagamaan serta berupaya mengadakan berbagai macam kegiatan dan aktivitas untuk masyarakat khususnya mahasiswa dan dosen dalam rangka untuk meningkatkan kehidupan beragama.

Sedangkan hasil wawancara dengan Ketua Remaja Masjid Imam Rijali IAIN Ambon, M. Umar Alkatiri menyatakan bahwa: bentuk program sedang di diskusikan antara Ustad Sarifuddin, M. Umar Alkatiri (saya sendiri selaku ketua remas) dan anggota-anggota lainnya untuk bermusyawarah bagaimana program apa saja yang akan dicamtumkan dalam remaja masjid. Salah satu program yang dilakukan Remaja 
Masjid Imam Rijali IAIN Ambon yaitu: program di bidang Dakwah, Kajian dan kenyamanan umat. $^{4}$

Hasil wawancara di atas penulis mengambil kesimpulan bahwa bentuk program telah diaktualisasikan dengan kegiatan operasional yang berjalan dengan program pembangunan Masjid. Umat Islam bersyukur bahwa dalam dekade akhir-akhir ini masjid semakin tumbuh dan berkembang, baik dari segi jumlahnya. Hal ini menunjukan adanya peningkatan kehidupan ekonomi umat, peningkatan gairah dan semaraknya kehidupan beragama.

\section{Aktivitas Remaja Masjid Imam Rijali IAIN Ambon yang mengandung nilai pendidikan Islam}

Menurut hasil wawancara dengan ketua remaja Masjid Imam Rijali IAIN Ambon, M. Umar Alkatiri ${ }^{5}$ menyatakan bahwa: "Aktivitas Remaja Masjid Imam Rijali IAIN Ambon untuk akhwat itu ada tugas-tugas tertentu. Misalnya kenyamanan umat mereka mempunyai tata kebersihan masjid, sedangkan untuk akhwat setaip minggu itu mereka mempunyai tugas untuk mencuci mukena-mukena yang ada di masjid, kemudian untuk inwan kita saling bercerita mengenai pelajaran-pelajaran yang di dapatkan di kampus, dan juga membaca al-Qur'an".

Sedangkan menurut ketua dakwah Andi S. Sowakil ia menyatakan bahwa: "Misalnya pada penyampaian kultum, di dalam kultum itu mengajarkan kita mengenai sabar. Dengan adanya penyampaian itu secara tidak langsung kita sudah menasehat diri kita sendiri". Menurut ketua kajian Ahmad Yani Raharusun menyatakan bahwa: ${ }^{6}$ "Kita lihat kultum ini bagaimana membiasakan orang untuk bagaimana mengajarkan mereka untuk berbicara di depan banyak orang dan itu juga merupakan salah satu bentuk medidik karakter seseorang". Sementara menurut ketua keputrian Umiati Masiri

\footnotetext{
${ }^{4}$ M.Umar Alkatiri, Ketua Remaja Masjid Imam Rijali IAIN Ambon , “Wawancara” Depan Fakultas Syariah IAIN Ambon, 10 Januari 2019.

${ }^{5}$ M. Umar Alkatiri, Ketua Remaja Masjid Imam Rijali IAIN Ambon, “ Wawancara” Depan Fakultas Syariah IAIN Ambon, 10 Januari 2019.

${ }^{6}$ Ahmad Yani Raharusun, Ketua Bidang Kajian, “ Wawancara”, Masjid Imam Rijali IAIN Ambon, 12 Januari 2019.
} 
ia menyatakan bahwa: "Aktivitas yang dilakukan dalam remaja masjid misalnya pembersihan masjid berarti aktivitas tersebut mengandung nilai pendidikan Islam karena kebersihan itu juga salah satu dari nilai Islam, kemudian menyelenggarakan maulid Nabi Muhammad SAW. Berarti kita sudah menerapkan nilai-nilai kelslaman di dalamnya. Kita sudah tahu bahwa karakter Rasululullah itu karakter sebaik-baik manusia jadi secara otomatis kita sudah menanamkan nilai-nilai Islam itu sendiri."

Menurut Ketua Remaja Masjid ia mengatakan bahwa: "Implementasi nilai-nilai Islam yang terdapat dalam aktivitas Remaja Masjid meliputi pembentukan karakter, ketauhidan, ibadah serta akhlak, nilai-nilai Islam itu di terapkan dalam aktivitas program yang terdapat di Remaja Masjid Imam Rijali IAIN Ambon."

Hasil wawancara di atas penulis mengambil kesimpulan bahwa aktivitas-aktivitas remaja Masjid Imam Rijali IAIN Ambon dalam kehidupan masyarakat keaktifan beribadah sangat diperlukan, mengingat keagamaan di lingkungan masyarakat cenderung dipengaruhi oleh faktor lingkungan dan kondisi kejiwaan masyarakat (mahasiswa), bisa dikatakan bahwa jika lingkungan masyarakat agamis dan bergaul dengan orang-orang yang memegang teguh keimanan maka kondisi agamanya akan berpengaruh menjadi baik dan juga sebaliknya. Maka dari itu dengan adanya kegiatankegiatan yang diadakan remaja masjid dapat mendorong masyarakat (mahasiswa) aktif dalam beribadah serta mengetahui tata cara, manfaat, fungsi dan kewajiban-kewajiban yang harus dilakukan oleh masyarakat (mahasiswa) sesuai dengan ajaran Islam. Dengan keaktifan beribadah inilah mencerminkan masyarakat (mahasiswa) yang mempunyai kehidupan beragama secara hakiki dan sesuai dengan ajaran Islam.

\section{PEMBAHASAN}

\section{Bentuk program Remaja Masjid Imam Rijali IAIN Ambon yang mengandung nilai pendidikan Islam}

Program adalah, suatu jenis rencana yang jelas dan konkret karena di dalamnya sudah tercantum sasaran, kebijaksanaan, prosedur, anggaran, dan waktu pelaksanaan yang dilakukan. Definisi program juga termuat dalam Undang-Undang RI Nomor 25 Tahun 2004 Tentang Sistem Perencanaan Pembangunan Nasional, menyatakan

\footnotetext{
${ }^{7}$ Umiati Masiri, Ketua Bidang Keputrian, "Wawancara” Masjid Imam Rijali IAIN Ambon, 14 Januari 2019.
} 
bahwa: ${ }^{8}$ Program adalah instrumen kebijakan yang berisi satu atau lebih kegiatan yang dilaksanakan oleh instansi pemerintah/lembaga untuk mencapai sasaran dan tujuan serta memperoleh alokasi anggaran atau kegiatan masyarakat yang dikoordinasikan oleh instansi masyarakat.

Menurut Ketua Remaja Masjid sendiri M.Umar Alkatiri ia mengatakan bahwa bentuk program sedang didiskusikan antara Ustad Sarifuddin, M. Umar Alkatiri (saya sendiri selaku ketua remas) dan anggota-anggota lainnya untuk bermusyawarah bagaimana program apa saja yang akan dicamtumkan dalam remaja masjid . Programprogram yang terdapat dalam organisai Remaja Masjid Imam Rijali IAIN Ambon diantaranya : program bidang dakwah (Mubaligh), Kajian kelslaman, Kenyamanan umat, koperasi dan keputrian. Dari program-program tersebut yang mengandung nilai pendidikan Islam diantaranya bisa dilihat dari cara remaja masjid mendiskusikan program-program tersebut, mereka memisahkan antara akhwat dan ikhwan, mereka juga menanamkan nilai-nilai Islam dalam bermusyawarah, membaca al-Qur'an sebelum membuka musyawarah mereka.

\section{Aktivitas Remaja Masjid Imam Rijali IAIN Ambon yang mengandung nilai pendidikan Islam.}

Dalam kamus besar bahasa Indonesia, aktivitas diartikan sebagai segala bentuk keaktifan dan kegiatan. Aktivitas adalah keaktifan, kegiatan-kegiatan, kesibukan atau bisa juga berarti kerja atau salah satu kegiatan kerja yang dilaksanakan tiap bagian dalam tiap suatu organisasi atau lembaga. Menurut ilmu sosiologis aktivitas diartikan sebagai segala bentuk kegiatan yang ada di masyarakat seperti gotong royong dan kerja sama disebut sebagai aktivitas sosial baik yang berdasarkan hubungan tetangga atau kekerabatan. ${ }^{9}$ Dalam kehidupan sehari-hari banyak sekali aktivitas, kegiatan, atau kesibukan yang dilakukan manusia, namun berarti atau tidaknya kegiatan tersebut bergantung pada individu tersebut.

Menurut ketua remaja masjid Imam Rijali IAIN Ambon ia mengatakan bahwa :

\footnotetext{
${ }^{8}$ Undang-Undang Ri Nomor 25 Tahun 2004 Tentang Sistem Perencanaan Pembangunan Nasional.

${ }^{9}$ Sojogyo Dan Pujiwati Soyogyo, Sosiologi Pedesaan Kumpulan Bacaan, (Yogyakarta : Gajah Mada Universty Press, 1999), Cet Ke 12 Jilid 1, Hlm 28.
} 
"Aktivitas-aktivitas yang terdapat di dalam remaja masjid yaitu ada 1) kultum sebelum shalat zhuhur, 2) pemberian kajian-kajian mengenai fiqih wanita, 3) pembersihan masjid setiap jumat, 4) pelatihan-pelatihan khutbah, da'i, 5) yasinan, 6) tahlilan yang akan dilakukan dengan UKM-UKM yang ada di kampus ini, kemudian untuk akhwat itu tugasnya mencuci mukena-mukena yang ada di masjid, itu setiap minggu dilaksanakan sedangkan untuk ikhwan itu biasanya katong ngobrol don punya pelajaran-pelajaran yang ada di dalam kampus yang memang sudah pernah dapat dan juga membaca al-Qur'an"10.

Kegiatan-kegiatan itu dapat disimpulkan bahwa kinerja Remaja Masjid Imam Rijali IAIN Ambon sudah sangat baik bagi mahasiswa dan para dosen, upaya yang dilakukan oleh Remaja Masjid Imam Rijali IAIN Ambon ini pengimplementasian nilainilai pendidikan Islam dalam aktivitas remaja masjid itu sendiri sudah efektif. Diantaranya : a) pembentukan karakter, b) ketauhidan, c) ibadah, d) akhlak. Selain mengamalkan nilai-nilai pendidikan Islam di dalam aktivitas Remaja Masjid, mereka juga mengkaitkan pendidikan-pendidikan umum di dalamnya. Misalnya terkait mata kuliah-mata kuliah mereka.

\section{KESIMPULAN}

Penelitian yang dilakukan peneliti dengan judul "Implementasi nilai-nilai pendidikan Islam dalam aktivitas Remaja Masjid Imam Rijali IAIN Ambon". Berdasarkan data yang diperoleh dari observasi, wawancara serta dokumentasi dapat disimpulkan sebagai berikut:

1. Bentuk program Remaja Masjid Imam Rijali IAIN Ambon yang mengandung nilai pendidikan Islam diantaranya: a) Program dakwah atau mubaligh, b) Program kajian kelslaman, c) Program kenyamanan umat, d) Program koperasi, e) Program keputrian. Program-program ini dibentuk dengan cara bermusyawarah antara Ketua Takmir Masjid, ketua remaja masjid dan para anggota lainnya.

2. Aktivitas Remaja Masjid Imam Rijali IAIN Ambon yang mengandung nilai pendidikan Islam antara lain : untuk para akhwat ada tugas-tugas tertentu a) pembersihan mukena-mukena, b) kajian-kajian fiqih wanita,c) pelatihan-pelatihan mubaligh-

\footnotetext{
${ }^{10}$ M.Umar Alkatiri, Ketua Remaja Masjid Imam Rijali IAIN Ambon, “Wawancara” depan fakultas syariah, 8 Januari 2019.
} 
mubaligh muda, d) pelatihan ceramah, e) pelatihan tahlil, f) yasinan, g) kultum sebelum shalat zhuhur, h) kajian-kajian kelslaman dan perayaan hari-hari besar Islam. Implementasi nilai-nilai Islam yang terdapat dalam aktivitas remaja masjid sendiri yaitu meliputi pembentukan karakter, ketauhidan, ibadah serta akhlak. Nilainilai Islam itu diterapkan melalui aktivitas program yang ada di Remaja Masjid Imam Rijali IAIN Ambon tersebut. Dengan adanya implementasi nilai-nilai Islam ini sangat mempengaruhi bagi remaja masjid termasuk didalamnya komponen mahasiswa itu sendiri yang sepenuhnya mendapat dukungan ketua takmir masjid.

\section{UCAPAN TERIMAKASIH}

Dengan mengucap syukur Alhamdulillah, kupersembahkan karya kecilku ini untuk orang-orang yang penulis sayangi: Alm. Ayahanda M. Yasin Walalayo dan Ibunda Binnur Tehuayo tercinta sebagai motivator terbesar yang selalu mendoakan penulis selama penulis mengikuti perkuliahan sampai saat ini walaupun Ayahanda telah tiada, tak terhingga penulis menyampaikan terima kasih yang sebanyak-banyaknya penulis selalu mendoakan yang terbaik untuk ayahanda semoga di tempatkan di syurganya Allah yang paling mulia. Amiinn, dan Ibunda yang paling tersayang, yang sampai saat ini selalu menjagaku.

Dalam hidup penulis selalu mendoakan dan menyayangi, terima kasih atas semua pengorbanan dan kesabaran mengantarkanku sampai kini, tak pernah cukup ananda membalas rasa kasih sayang dan pengorbanan tersebut. Syukron katsir for my father

and my mother, Keluarga Besar, para Dosen, dan sahabat-sahabatkku yang sangat penulis sayangi serta almamater tercinta.

\section{DAFTAR PUSTAKA}

[1] Roqib, Moh. 2005. Menggugat Fungsi Edukasi Masjid, Purwokerto: STAIN Purwokerto dan Grafindo Litera Media.

[2] Safri Harahap, Sofyan. 1996. Manajemen Masjid, Yogyakarta: Dhana Bhakti Prima, 1996.

[3] Sarwono, Ahmad. 2003. Masjid Jantung Masyarakat, Yogyakarta : Izzan Pustaka. 
[4] Sojogyo dan Pujiwati Soyogyo. 1999. Sosiologi Pedesaan Kumpulan BacaaN, Yogyakarta : Gajah Mada Universty Press.

[5] Undang-Undang Ri Nomor 25 Tahun. 2004. Tentang Sistem Perencanaan Pembangunan Nasional. 